\title{
Electrochemical Oxidation of Fragrances 4-Allyl and 4-Propenylbenzenes on Platinum and Carbon Paste Electrodes
}

\author{
Lai-Hao Wang, ${ }^{*}$ Chia-Ling Chang, and Yi-Chun Hu \\ Department of Medical Chemistry, Chia Nan University of Pharmacy and Science, \\ 60 Erh-Jen Road, Section 1, Jen Te, Tainan 71743, Taiwan
}

RECEIVED MAY 19, 2013; REVISED MARCH 10, 2014; ACCEPTED JULY 21, 2014

\begin{abstract}
The electrochemical oxidation behaviors of 4-allylbenzenes (estragole, safrole and eugenol) and 4-propenylbenzenes (anethole, asarone and isoeugenol) on platinum and carbon paste electrodes were investigated in a Britton-Robinson buffer $(\mathrm{pH}=2.93$ and 10.93), acetate buffer, phosphate buffer solutions $(\mathrm{pH}=2.19$ and 6.67$)$, and acetonitrile containing various supporting electrolytes examined lithium perchlorate. Their oxidation potential with Hammett (free-energy relationships) and possible reaction mechanisms were discussed.
\end{abstract}

Keywords: electrochemical oxidation, 4-allylbenzenes, 4-propenylbenzenes

\section{INTRODUCTION}

Research on fragrances / flavors is popular; however, almost all studies focus on their wide application in the food, and cosmetics industries and in traditional medicine; as well as extraction methods and analytical methodologies. ${ }^{1-5}$ Fragrances that are air-sensitive may form peroxides, respiratory irritants, and aerosol particles that cause inflammatory responses in the lungs. The photochemistry of some allylic compounds such as cis-trans isoeugenol and citral, were oxidized in the presence of atmospheric oxygen or photosensitized species $\left(\mathrm{O}_{3}, \mathrm{OH}, \mathrm{NO}_{3}\right.$, etc. $\left.)\right)^{6-8}$ However, most reports have focused on the photochemical reaction of eugenol derivatives to for the synthesis of new flavors chemicals. ${ }^{9-14}$ The structurally related substituted 4-allylbenzenes derivatives (eugenol, estragole and safrole) and 4-propenylbenzenes derivatives (isoeugenol, anethole and asarone), occur naturally in various traditional foods, particularly in spices such as cloves, cinnamon and basill. Some of them have been demonstrated to be an effective, inexpensive anesthetic agents, antioxidants and blood circulation enhancers. The major analytical methods for analyzing alkenylbenzenes fragrances are gas chromatography and gas chromatography-mass spectrometry. ${ }^{15}$ There are few electrochemical theories reported in pharmaceutical formulations. ${ }^{16}$ 4-allylbenzenes (4-allylanisole and eugenol) and 4-propenylbenzenes (trans-anethole) are studied to undergo electrochemical polymerization giving rise to either conducting or insulating films. ${ }^{17-19}$ The anodic methoxylation of alkenylbenzenes includes anethole and isosafrole on graphite and platinum, which can be converted to free aldehyde, a valuable fragrance compound and an intermediate for organic synthesis. ${ }^{20-23}$ The present work is concerned with the measurement of aromatic substituent effects and structural elucidation of 4-allyl and 4-propenylbenzenes.

\section{EXPERIMENTAL}

\section{Apparatus and Materials}

Voltammetric measurements were performed using an EG\&G Princeton Applied Research Model 394 Polarographic Analyzer (Princeton, NJ, USA) and potentiostat/galvanostat (263A; EG\&G Princeton Applied Research, Princeton, NJ, USA).The absorption spectra of fragrances were determined using a spectrophotometer (2000/IRDM FTIR; Perkin-Elmer, Fremont, CA, USA) with an attenuated total reflection (ATR) system (Gateway ATR; SpecacInc., Smyrna, GA (now Cranston, RI), USA). The Raman spectra were recorded using a micro-Raman setup (JASCO NR-1000; Sunway Scientific Corporation, Taipei, Taiwan). The spectrometer had a focal length of $300 \mathrm{~nm}$ and was equipped with a dispersive element 1800 lines $/ \mathrm{mm}$ grating, resulting in a resolution of $1.2 \mathrm{~cm}^{-1}$.

\footnotetext{
* Author to whom correspondence should be addressed. (E-mail: e201466.wang@msa.hinet.net)
} 
Pure standard substances were purchased from biomedical supply houses: eugenol, isoeugenol, and transanethole from Acros Organics, Geel, Belgium; $\alpha$-asarone, safrole from Sigma-Aldrich Fine Chemicals, Fluka, Switzerland; estragole from Aldrich Chemical Company, Inc., Milwaukee, WI. Supporting electrolytes were obtained as follows: tetrabutylammonium tetrafluoroborate $\left(\mathrm{Bu}_{4} \mathrm{NBF}_{4}\right.$, Acros Organics, Thermo Fisher Scientific, Geel, Belgium), tetraethylammonium tetrafluoroborate $\left(\mathrm{Et}_{4} \mathrm{NBF}_{4}\right.$, E. Merck, Chemical Co. Germany), tetrabutylammonium perchlorate $\left(\mathrm{Bu}_{4} \mathrm{NClO}_{4}\right.$, Tokyo Chemical Industry Co., Ltd, Tokyo, Japan), tetraethylammonium perchlorate $\left(\mathrm{Et}_{4} \mathrm{NClO}_{4}\right.$, Tokyo Chemical Industry Co., Ltd, Tokyo, Japan), and lithium perchlorate $\left(\mathrm{LiClO}_{4}\right.$, Acros Organics, Thermo Fisher Scientific,Geel, Belgium). Other chemical reagents used were of analytical grade.

\section{Voltammetric Measurements}

The three voltammetric techniques, Sampling DC, linear Sweep and cyclic voltammetry, were all performed on a platinum and carbon paste electrodes. Cyclic voltamograms $(\mathrm{CV})$ of the fragrances were taken on a platinum electrode in acetonitrile containing various supporting electrolytes, and Britton-Robinson buffer solutions $(\mathrm{pH}=$ $2.93-10.93$ ) to monitor potential vs. current.

\section{RESULTS AND DISCUSSION}

\section{Electrochemical Behavior of Fragrances 4-Allyl and 4-Propenylbenzenes on the Platinum Electrode}

Supporting Electrolytes and Solvent Effects

There are several ways in which the supporting electrolytes solvent system can influence mass transfer, the electron reaction (electron transfer), and the chemical reactions which are coupled to the electron transfer. ${ }^{24}$ The effects of supporting electrolytes and solvent composition on fragrances 4-allyl and 4-propenylbenzenes peak potential $\left(E_{\mathrm{p}}\right)$ and peak current $\left(i_{\mathrm{p}}\right)$ are listed in Table 1. Table 1 shows the peak current of fragrances in non-aqueous solvent (100\% acetonitrile) were higher than in aqueous-organic solvent (30\% acetonitrile) due to the higher background in non-aqueous solvent than that in aqueous-organic solvent. However, the peak potential of fragrances were less positive in aqueous organic solvents that are more suitable for oxidation. The electrooxidation process occurs in the heterogeneous phase. For non-aqueous solvent, its molecules completely cover the electrode surface to prevent the adsorption of fragrances. Furthermore in organic work, strongly basic anions or radical anions are often produced and these are rapidly protonated by solvents like

Table 1. Effect of supporting electrolytes on the cyclic voltammetric peak potential $\left(E_{\mathrm{p}}\right)$ and peak current $\left(i_{\mathrm{p}}\right)$ of $\alpha$-asarone, transanethole, isoeugenol, safrole, estragole and eugenol at platinum electrode. The concentration of fragrances was $1 \mathrm{mmol} \mathrm{dm}^{-3} ; \mathrm{scan}^{-}$ rate, $v=50 \mathrm{mV} / \mathrm{s}$.

\begin{tabular}{|c|c|c|c|c|c|c|c|c|c|c|c|c|}
\hline & \multicolumn{2}{|c|}{$\alpha$-Asarone } & \multicolumn{2}{|c|}{ trans-Anethole } & \multicolumn{2}{|c|}{ Isoeugenol } & \multicolumn{2}{|c|}{ Safrole } & \multicolumn{2}{|c|}{ Estragole } & \multicolumn{2}{|c|}{ Eugenol } \\
\hline & $E_{\mathrm{p}} / \mathrm{V}$ & $i_{\mathrm{p}} / \mu \mathrm{A}$ & $E_{\mathrm{p}} / \mathrm{V}$ & $i_{\mathrm{p}} / \mu \mathrm{A}$ & $E_{\mathrm{p}} / \mathrm{V}$ & $i_{\mathrm{p}} / \mu \mathrm{A}$ & $E_{\mathrm{p}} / \mathrm{V}$ & $i_{\mathrm{p}} / \mu \mathrm{A}$ & $E_{\mathrm{p}} / \mathrm{V}$ & $i_{\mathrm{p}} / \mu \mathrm{A}$ & $E_{\mathrm{p}} / \mathrm{V}$ & $i_{\mathrm{p}} / \mu \mathrm{A}$ \\
\hline $\mathrm{Bu}_{4} \mathrm{NBF}_{4} / \mathrm{CH}_{3} \mathrm{CN}$ & $\begin{array}{l}0.91 \\
1.19 \\
1.44\end{array}$ & $\begin{array}{l}20.6 \\
36.2 \\
34.6\end{array}$ & $\begin{array}{l}1.33 \\
1.78 \\
2.14\end{array}$ & $\begin{array}{l}35.7 \\
72.9 \\
136\end{array}$ & $\begin{array}{l}0.84 \\
1.18 \\
1.42\end{array}$ & $\begin{array}{l}24.4 \\
54.5 \\
94.5\end{array}$ & $\begin{array}{r}1.57 \\
1.78 \\
-\quad \text { (a) }\end{array}$ & $\begin{array}{c}62.0 \\
62.6 \\
- \text { (a) }\end{array}$ & $\begin{array}{c}1.67 \\
2.12 \\
-{ }^{(a)}\end{array}$ & $\begin{array}{c}80.1 \\
98.2 \\
\quad \text { (a) }\end{array}$ & $\begin{array}{r}1.17 \\
{ }_{-}^{(\text {a) }} \\
\text { - }^{\text {(a) }}\end{array}$ & $\begin{array}{r}44.9 \\
-{ }^{\text {(a) }} \\
\text { (a) }^{\text {(a) }}\end{array}$ \\
\hline $\mathrm{Et}_{4} \mathrm{NBF}_{4} / \mathrm{CH}_{3} \mathrm{CN}$ & $\begin{array}{l}0.99 \\
1.31 \\
1.86\end{array}$ & $\begin{array}{l}30.3 \\
28.8 \\
45.9\end{array}$ & $\begin{array}{l}1.31 \\
1.68 \\
2.11\end{array}$ & $\begin{array}{l}28.8 \\
46.9 \\
98.0\end{array}$ & $\begin{array}{l}1.10 \\
1.25 \\
1.52\end{array}$ & $\begin{array}{l}26.2 \\
38.9 \\
45.8\end{array}$ & $\begin{array}{c}1.51 \\
1.88 \\
-{ }^{(a)}\end{array}$ & $\begin{array}{r}41.6 \\
84.6 \\
-{ }^{(a)}\end{array}$ & $\begin{array}{c}1.67 \\
2.13 \\
-{ }_{(a)}\end{array}$ & $\begin{array}{l}61.3 \\
75.1 \\
-{ }^{(a)}\end{array}$ & $\begin{array}{c}1.23 \\
-(a) \\
-(a)\end{array}$ & $\begin{array}{r}35.1 \\
- \text { (a) } \\
-{ }^{(a)}\end{array}$ \\
\hline $\mathrm{Bu}_{4} \mathrm{NClO}_{4} / \mathrm{CH}_{3} \mathrm{CN}$ & $\begin{array}{l}1.20 \\
1.43 \\
1.71\end{array}$ & $\begin{array}{l}31.6 \\
37.6 \\
49.0\end{array}$ & $\begin{array}{l}1.26 \\
1.65 \\
2.06\end{array}$ & $\begin{array}{c}49.2 \\
69.6 \\
150\end{array}$ & $\begin{array}{l}1.10 \\
1.27 \\
1.51\end{array}$ & $\begin{array}{l}29.0 \\
41.5 \\
42.4\end{array}$ & $\begin{array}{c}1.51 \\
1.80 \\
-{ }^{\text {(a) }}\end{array}$ & $\begin{array}{c}57.2 \\
58.9 \\
-{ }^{(a)}\end{array}$ & $\begin{array}{r}1.67 \\
2.06 \\
-{ }^{(a)}\end{array}$ & $\begin{array}{c}54.9 \\
82.5 \\
-{ }^{(a)}\end{array}$ & $\begin{array}{r}1.27 \\
-{ }^{(a)} \\
{ }_{-}{ }^{(a)}\end{array}$ & $\begin{array}{r}41.0 \\
-\quad \text { (a) } \\
-{ }^{\text {(a) }}\end{array}$ \\
\hline $\mathrm{Et}_{4} \mathrm{NClO}_{4} / \mathrm{CH}_{3} \mathrm{CN}$ & $\begin{array}{l}1.15 \\
1.40 \\
1.72\end{array}$ & $\begin{array}{l}35.5 \\
41.4 \\
49.8\end{array}$ & $\begin{array}{l}1.32 \\
1.67 \\
2.11\end{array}$ & $\begin{array}{c}34.2 \\
51.0 \\
115\end{array}$ & $\begin{array}{l}1.08 \\
1.27 \\
1.48\end{array}$ & $\begin{array}{l}28.5 \\
44.7 \\
49.0\end{array}$ & $\begin{array}{c}1.49 \\
1.81 \\
-{ }^{\text {(a) }}\end{array}$ & $\begin{array}{l}41.7 \\
42.1 \\
-{ }^{(a)}\end{array}$ & $\begin{array}{c}1.64 \\
2.13 \\
\quad \text { (a) }\end{array}$ & $\begin{array}{c}69.7 \\
83.7 \\
-{ }^{(a)}\end{array}$ & $\begin{array}{r}1.18 \\
-{ }^{\text {(a) }} \\
\text { (a) }^{(a)}\end{array}$ & $\begin{array}{r}41.7 \\
-{ }^{\text {(a) }} \\
-{ }^{\text {(a) }}\end{array}$ \\
\hline $\mathrm{LiClO}_{4} / \mathrm{CH}_{3} \mathrm{CN}$ & $\begin{array}{l}1.13 \\
1.36 \\
1.73\end{array}$ & $\begin{array}{l}32.8 \\
33.3 \\
37.9\end{array}$ & $\begin{array}{l}1.25 \\
1.60 \\
2.00\end{array}$ & $\begin{array}{c}32.8 \\
59.6 \\
114\end{array}$ & $\begin{array}{l}1.00 \\
1.18 \\
1.43\end{array}$ & $\begin{array}{l}27.6 \\
45.4 \\
55.3\end{array}$ & $\begin{array}{r}1.39 \\
2.09 \\
-{ }^{(a)}\end{array}$ & $\begin{array}{l}42.2 \\
62.7 \\
-{ }^{(a)}\end{array}$ & $\begin{array}{c}1.61 \\
2.07 \\
\quad \text { (a) }\end{array}$ & $\begin{array}{l}51.1 \\
7.81 \\
-{ }^{(a)}\end{array}$ & $\begin{array}{c}1.16 \\
-{ }^{\text {(a) }} \\
{ }_{-}{ }^{(a)}\end{array}$ & $\begin{array}{r}42.2 \\
-{ }^{(a)} \\
-{ }^{(a)}\end{array}$ \\
\hline $\begin{array}{l}\mathrm{Et}_{4} \mathrm{NBF}_{4} / \mathrm{CH}_{3} \mathrm{CN} \\
w\left(\mathrm{CH}_{3} \mathrm{CN}\right)=30 \%\end{array}$ & $\begin{array}{l}0.76 \\
0.99\end{array}$ & $\begin{array}{l}12.7 \\
21.7\end{array}$ & $\begin{array}{l}1.11 \\
1.57\end{array}$ & $\begin{array}{c}24.2 \\
67.17\end{array}$ & $\begin{array}{l}0.61 \\
-{ }^{(a)}\end{array}$ & $\begin{array}{l}9.81 \\
-{ }_{-}^{(a)}\end{array}$ & $\begin{array}{l}1.18 \\
-(\mathrm{a})\end{array}$ & $\begin{array}{r}47.3 \\
-{ }^{(a)}\end{array}$ & $\begin{array}{l}1.37 \\
-\end{array}$ & $\begin{array}{l}42.0 \\
-{ }^{(a)}\end{array}$ & $\begin{array}{l}0.85 \\
-{ }^{(a)}\end{array}$ & $\begin{array}{r}23.7 \\
-(\mathrm{a})\end{array}$ \\
\hline $\begin{array}{l}\mathrm{Et}_{4} \mathrm{NClO}_{4} / \mathrm{CH}_{3} \mathrm{CN} \\
w\left(\mathrm{CH}_{3} \mathrm{CN}\right)=30 \%\end{array}$ & $\begin{array}{l}0.76 \\
0.97\end{array}$ & $\begin{array}{l}11.0 \\
17.1\end{array}$ & $\begin{array}{l}1.00 \\
1.58\end{array}$ & $\begin{array}{l}20.9 \\
69.04\end{array}$ & $\begin{array}{l}0.64 \\
-{ }^{(a)}\end{array}$ & $\begin{array}{l}9.00 \\
-{ }^{(a)}\end{array}$ & $\begin{array}{l}1.17 \\
-{ }^{(a)}\end{array}$ & $\begin{array}{l}51.8 \\
-{ }^{(a)}\end{array}$ & $\begin{array}{l}1.37 \\
-{ }_{-}^{(a)}\end{array}$ & $\begin{array}{l}48.9 \\
-{ }^{(a)}\end{array}$ & $\begin{array}{l}0.83 \\
-{ }^{(a)}\end{array}$ & $\begin{array}{r}18.9 \\
-(\mathrm{a})\end{array}$ \\
\hline $\begin{array}{c}\mathrm{LiClO}_{4} / \mathrm{CH}_{3} \mathrm{CN} \\
w\left(\mathrm{CH}_{3} \mathrm{CN}\right)=30 \%\end{array}$ & $\begin{array}{l}0.76 \\
0.97\end{array}$ & $\begin{array}{l}12.9 \\
21.1\end{array}$ & $\begin{array}{l}1.11 \\
-(\mathrm{a})\end{array}$ & $\begin{array}{l}20.8 \\
-(\text { a) }\end{array}$ & $\begin{array}{r}0.69 \\
-{ }^{(a)}\end{array}$ & $\begin{array}{r}9.56 \\
-(a)\end{array}$ & $\begin{array}{r}1.19 \\
-(\mathrm{a})\end{array}$ & $\begin{array}{l}48.8 \\
-(\mathrm{a})\end{array}$ & $\begin{array}{l}1.38 \\
-(\mathrm{a})\end{array}$ & $\begin{array}{l}56.1 \\
-(\text { a) }\end{array}$ & $\begin{array}{l}0.92 \\
-(\mathrm{a})\end{array}$ & $\begin{array}{r}17.8 \\
-(\mathrm{a})\end{array}$ \\
\hline
\end{tabular}

(a) Not determined 
water or alcohol. These reasons explain why aqueous organic solvents are more suitable for the oxidation of the allyl and propenylbenzenes. The solubilities and specific resistance of $\mathrm{Bu}_{4} \mathrm{NBF}_{4} / \mathrm{CH}_{3} \mathrm{CN}(s=70 \mathrm{~g} / 100$ $\mathrm{ml}, \rho=37 \Omega \mathrm{m})$ and $\mathrm{Bu}_{4} \mathrm{NClO}_{4} / \mathrm{CH}_{3} \mathrm{CN}(s=71 \mathrm{~g} / 100$ $\mathrm{ml}, \rho=31 \Omega \mathrm{m})$ are very near. Therefore, the $E_{\mathrm{p}}$ and $i_{\mathrm{p}}$ of the fragrances are very the similar.

The cation of the supporting electrolytes significantly influencing the safrole, estragole and eugenol on $E_{\mathrm{p}}$ and $i_{\mathrm{p}}$ is confirmed by the results listed in Table 1 . From Table 1, it is $1.51 \mathrm{~V}$ for $\mathrm{Bu}_{4} \mathrm{NClO}_{4}$ and $1.49 \mathrm{~V}$ for $\mathrm{Et}_{4} \mathrm{NClO}_{4}$ but the $i_{\mathrm{p}}$ in $\mathrm{CH}_{3} \mathrm{CN}$ containing $\mathrm{Bu}_{4} \mathrm{NClO}_{4}$ $(57.2 \mu \mathrm{A})$ is 1.4 times that of in $\mathrm{Et}_{4} \mathrm{NClO}_{4}(41.7 \mu \mathrm{A})$. These results can be accounted for by the presence of larger ion tetrabutylammonium than the tetraethylammonium film on the platinum surface. However, the $E_{\mathrm{p}}$ of quaternary ammonium ion film on the $\mathrm{Pt}$ surface is very similar. Compared with quaternary ammonium ion and $\left(\mathrm{R}_{4} \mathrm{~N}^{+}\right)$lithium ion $\left(\mathrm{Li}^{+}\right)$, the $E_{\mathrm{p}}$ of the safrole in $\mathrm{Bu}_{4} \mathrm{NClO}_{4}, \mathrm{Et}_{4} \mathrm{NClO}_{4}$ and $\mathrm{LiClO}_{4}$, small cation size of lithium ion show less positive values $(1.39 \mathrm{~V})$ than quaternary ammonium ion (1.57 V) (Figure 1).Indeed, as reported in the literature, ${ }^{25}$ the bulky hydrophobic alkyl group stronger Van der Waals forces of cohesion between the ammonium groups, leading to a more compact hydrophobic adsorbed layer. The $E_{\mathrm{p}}$ of the estrogole first peaks are expected to correspond to the processes of two a one-electron $\left(E_{\mathrm{p}}\right.$ at $1.67 \mathrm{~V}$ and $\left.2.13 \mathrm{~V}\right)$ and a one two-electron ( $E_{\mathrm{p}}$ at $1.37 \mathrm{~V}$ ) oxidation, in nonaqueous solvent (acetonitrile) and aqueous-organic solvent (30\% acetonitrile) (Figure 2). These data show the peak potentials shift more positively with $100 \%$ acetonitrile, because its molecules completely cover the electrode surface to prevent the adsorption of estragole. However, $30 \%$ acetonitrile point to an appreciable content of estragole adsorbed on the electrode surface. ${ }^{26}$

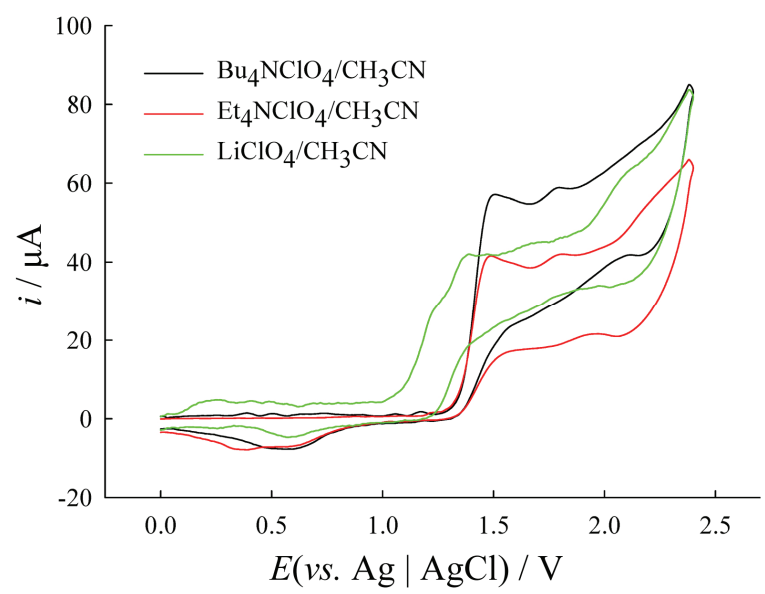

Figure 1. The effect of solvent (acetonitrile) containing various supporting electrolytes on the cyclic voltamograms of safrole at platinum electrode. Supporting electrolytes: tetrabutylammonium perchlorate $\left(\mathrm{Bu}_{4} \mathrm{NClO}_{4}\right)$; tetraethylammonium perchlorate $\left(\mathrm{Et}_{4} \mathrm{NClO}_{4}\right)$; lithium perchlorate $\left(\mathrm{LiClO}_{4}\right)$.

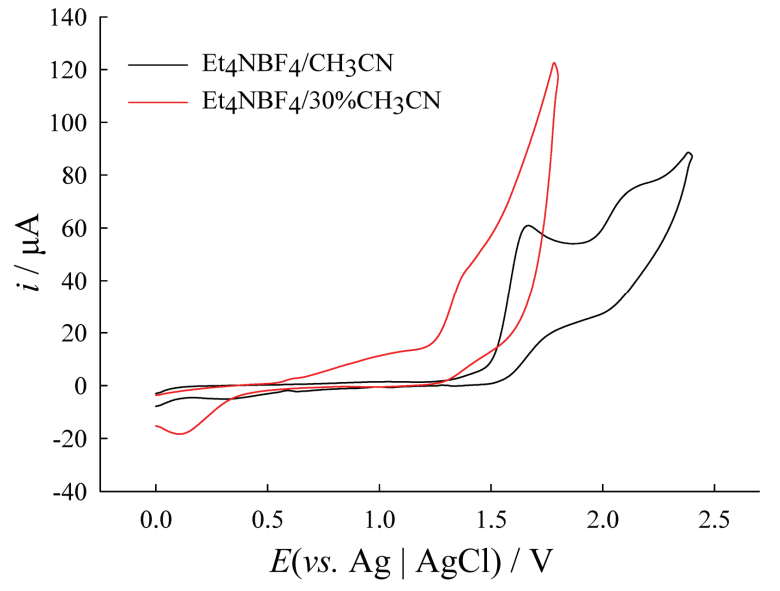

Figure 2. The effect of nonqueous aprotic solvent (acetonitrile) and $30 \%$ acetonitrile containing $\mathrm{Et}_{4} \mathrm{NBF}_{4}$ on the cyclic voltamograms of estragole at platinum electrode.

The total number of electrons is determined using controlled-potential coulometry using a platinum electrode. The accumulated charge $(Q)$ is taken from the digital coulometer at a curve (potential corresponding to peak current) of the oxidation wave. Applying the equation: $Q=n F w / M$ where $w$ is the weight of the sample in grams and $M$ its molecular weight, the value of $n$ for estrogole is found to be two electrons. ${ }^{19,27}$ The active oxidation group $(\mathrm{OH})$ on benzene ring of estrogole because of between $\mathrm{C}=\mathrm{C}$ double bond and benzene ring has not conjugation results a marked higher potential $(1.61 \mathrm{~V})$ than that has conjugation of trans-anethole $(1.25 \mathrm{~V})$ in acetonitrile containing $\mathrm{LiClO}_{4}$. A possible mechanism is given as below:<smiles>C=CCc1ccc(OC)cc1</smiles><smiles>C=CCc1ccc(OC)cc1</smiles>

Substituted Group Effects

Insofar as electrons are transferred in the potentialdetermining step, the transition state is more electron rich than the reactant is, and electron-donating substituents will facilitate to oxidation process. ${ }^{28}$ Voltammetric oxidative groups (i.e. hydroxyl and methoxyl) are electron-donating substituents these attached to the 4-allylbenzene nucleus and 4-propenylbenzenes (structure shown in Scheme 1) will affect the electronic distribution within that nucleus. The substituents constant values can be quantitatively divided into the sum of 
<smiles>C=CCc1ccc(O)c(OC)c1</smiles><smiles>C=CCc1ccc(OC)cc1</smiles><smiles>C=CCc1ccc2c(c1)OCO2</smiles>

Eugenol<smiles>C/C=C/c1ccc(O)c(OC)c1</smiles>

Isoeugenol<smiles>C/C=C/c1cc([O-])c(OC)c(OC)c1</smiles>

$\alpha$ - asarone<smiles>C/C=C/c1ccc(OC)cc1</smiles>

trans-anethole

Scheme 1. The fragrance structure of eugenol, estragole, safrole, isoeugenol, $\alpha$-asarone, and trans-anethole.

independent inductive and resonance contributions. ${ }^{29}$ The following peak potentials are reported for substituted 4-allylbenzenes in $\mathrm{LiClO}_{4} / \mathrm{CH}_{3} \mathrm{CN}\left(w\left(\mathrm{CH}_{3} \mathrm{CN}\right)=\right.$ $100 \%$ ): hydroxyl $+1.16 \mathrm{~V}$, methoxyl $+1.64 \mathrm{~V}$ and methylenedioxy $+1.49 \mathrm{~V}$. (Figure 3) Eugenol is oxidized more easily than the estragole and safrole. The same substituents at 4-propenylbenzenes have resonance effect because involves interaction between double bond and benzene ring, and give three peaks. Figure 4 demonstrates the effect of the hydroxyl and methoxyl substituents on the oxidation of isoeugenol and transanethole and both have three peaks.

The vibrational spectroscopic features of fragrances demonstrate the relationship between substituents and

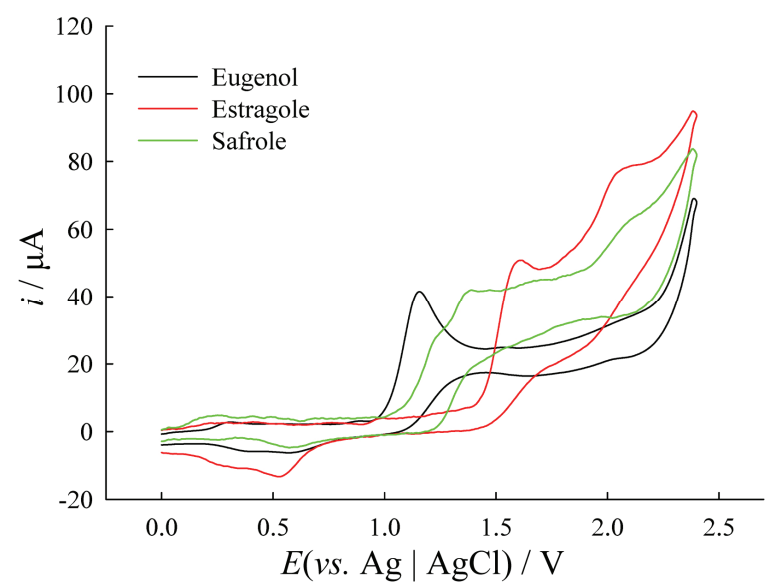

Figure 3. The effect of substituted 4-allylbenzences at platinum electrode in nonqueous aprotic solvent (acetonitrile) containing lithium perchlorate $(\mathrm{LiClO} 4 / 100 \% \mathrm{CH} 3 \mathrm{CN})$.

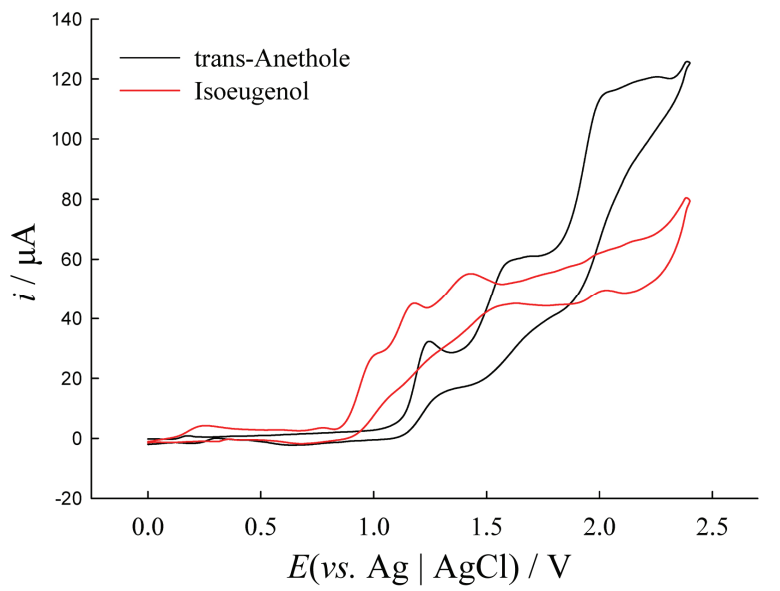

Figure 4. The effect of substituted 4-propenylbenzences at platinum electrode in nonqueous aprotic solvent (acetonitrile) containing lithium perchlorate $(\mathrm{LiClO} 4 / 100 \% \mathrm{CH} 3 \mathrm{CN})$.

vinyl double bond. Both ATR-IR and Raman have $\mathrm{C}=\mathrm{C}$ aromatic and conjugate bands about of 1600 $\mathrm{cm}^{-1}$ (Figure 5(a) and (b)). The ATR-IR spectra of 4-allylbenzenes (safrole, estragole and eugenol) have
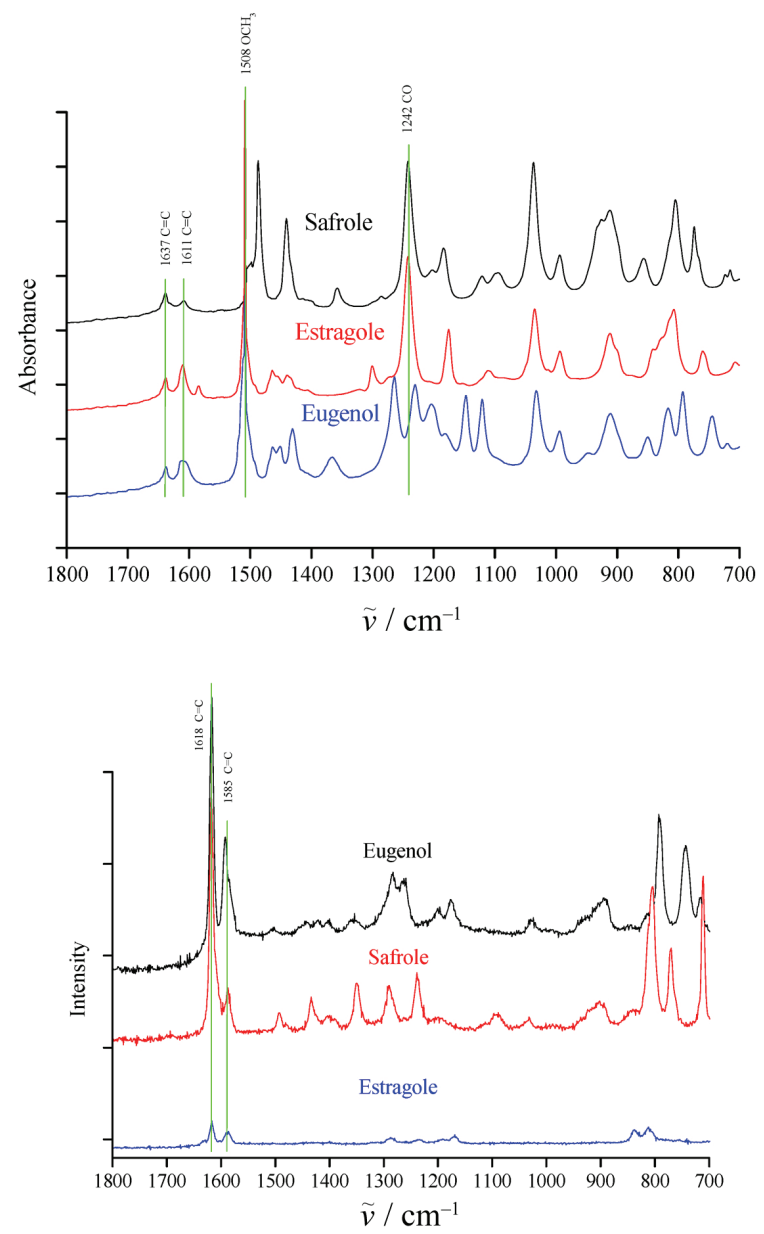

Figure 5. (a) ATR-IR spectroscopy for structure of 4-allylbenzenes (safrole, estragole ansd eugenol) (b) Raman spectroscopy for structure of 4-allylbenzenes (safrole, estragole and eugenol) 
highly similar characteristics because of the presence of the same weak bands $1611 \mathrm{~cm}^{-1}$ for $v(\mathrm{C}=\mathrm{C})_{a r}$ and $1637 \mathrm{~cm}^{-1}$ for $v(\mathrm{C}=\mathrm{C})_{\text {vin }}$, strong band $1508 \mathrm{~cm}^{-1}$ for $v\left(-\mathrm{OCH}_{3}\right)$ in estragole and eugenol, and strong band $1242 \mathrm{~cm}^{-1}$ for $v(\mathrm{C}-\mathrm{O})$. On the other hand, the Raman spectra of these compounds show quite similar strong bands at $1584 \mathrm{~cm}^{-1}$ for $v(\mathrm{C}=\mathrm{C})_{a r}$ and $1618 \mathrm{~cm}^{-1}$ for $v(\mathrm{C}=\mathrm{C})_{\text {vin }}$. However, from Figure 6 shows $1637 \mathrm{~cm}^{-1}$ for $v(\mathrm{C}=\mathrm{C})_{v i n}$ in trans-anethole is not apparent because of the resonance effect between the double bond and the benzene ring.

\section{Fragrances on the Platinum and Carbon Paste Electrodes}

\section{pH Effects}

The $E_{\mathrm{p}}$ and $i_{1}$ in the Sampling DC voltammetric oxidation over a wide $\mathrm{pH}$ range are found to substantially vary from each other. The $E_{\mathrm{p}}$ and $i_{1}$ obtained in the present work on the platinum and carbon electrodes are listed in Table 2. Notes, the $E_{\mathrm{p}}$ decreasing with an increasing $\mathrm{pH}$ does not obviouslly change in weak acidic media ( $\mathrm{pH}=2.93-5.39)$, but significantly decreased above $\mathrm{pH}=6.14$. Safrole and estragole differing from the other fragrances have two peaks above $\mathrm{pH}=6.14$ in alkaline media. However, there are two discrepancies between the voltammetric behaviors on the platinum $(\mathrm{Pt})$ and carbon paste electrodes (CPE): (1) A higher value of limiting current $\left(i_{1}\right)$ in strong acidic media $(\mathrm{pH}$ $=2.93-3.89)$ at $\mathrm{CPE}$; but higher $\mathrm{i}_{1}$ in weak acidic media $(\mathrm{pH}=6.18-6.83)$ at $\mathrm{Pt}$; (2) $E_{\mathrm{p}}$ decreasing with an increasing $\mathrm{pH}$ at $\mathrm{Pt}$ is clearly more regular than that CPE. Our analyses of the effect of $\mathrm{pH}$ and supporting electrolytes on the oxidation peak current and peak potential of fragrances in acidic solutions $(\mathrm{pH}=2.19-6.83)$ and in the electrolyte of lithium perchlorate $(\mathrm{pH}=6.04)$ showed the peaks shifted to a less to positive potential in acetate buffer and that the peak current in phosphate buffer $(\mathrm{pH}=$ 2.19) was higher than in the others (Figure 7). This indicates the oxidation of fragrances is strongly $\mathrm{pH}$ dependent. The $E_{\mathrm{p}}-E_{\mathrm{p} / 2}\left(E_{\mathrm{p} / 2}=\right.$ half- peak potential $)$ values in $\mathrm{pH}=2.93-8.81$ at $\mathrm{Pt}$ and $\mathrm{CPE}$ electrodes are shown in Table 3. $E_{\mathrm{p}}-E_{\mathrm{p} / 2}$ gave a range of $90-190 \mathrm{mV}$ and $80-170 \mathrm{mV}$ in acidic media at the Pt and CPE electrodes respectively. For a reversible charge transfer, the $E_{\mathrm{p}}-E_{\mathrm{p} / 2}$ should be around $60 \mathrm{mV}\left(E_{\mathrm{p}}-E_{\mathrm{p} / 2}=47.7\right.$ $\mathrm{mV} / \alpha n_{\mathrm{a}}$ at $\left.298 \mathrm{~K}\right)$. Hence, it may be concluded the mechanism for the oxidation of fragrance is an irreversible charge transfer at both Pt and CPE electrodes in acidic media. At a pH below 6.14, only one-electron peak was observed since the second one-electron step is obscured by hydrogen evolution. The $\alpha$-Asarone and eugenol undergoes oxidation in two steps (two one-electron), which are observed at $\mathrm{pH}$ above 6.83 and shown in Table 3.

The effect scan rate on the electrooxidation of isoeugenol was examined in $\mathrm{pH}=6.14$ in the range of

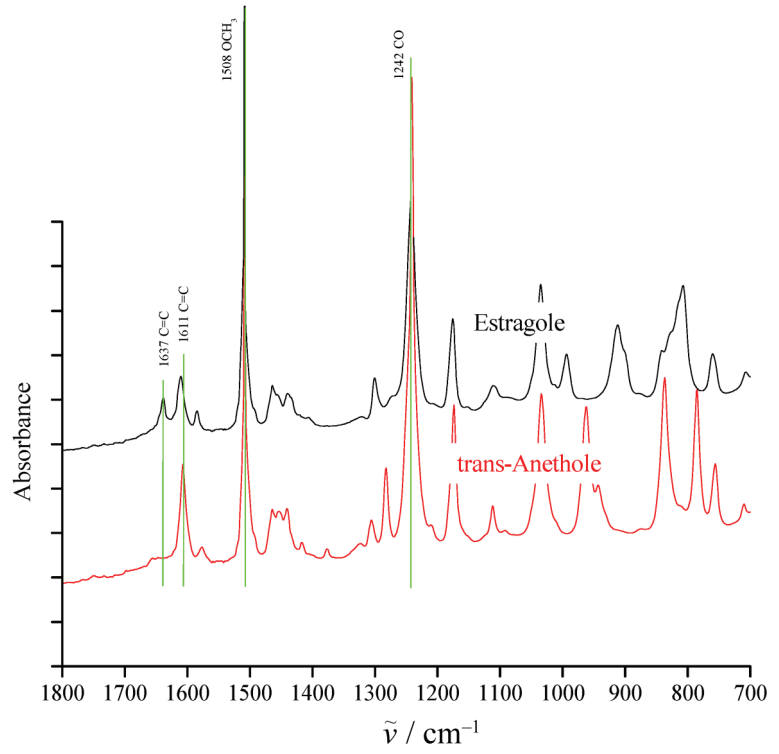

Figure 6. ATR-IR difference spectroscopy for structure of 4-allylbenzene (estragole) And 4-propenylbenzene (transAnethole)

$10 \mathrm{mV} / \mathrm{s}$ to $800 \mathrm{mV} / \mathrm{s}$. In this case the oxidative peak current was proportional to the square root of the scan rate on Pt and CPE electrodes, respectively. From Figure $8 \mathrm{~A}$, good linearity of the regression equation being $y=11.4 x+70.3$, the correlation coefficient $r=0.9900$ for Pt electrode; $y=2.45 x-5.27$, the correlation coefficient $r=0.9961$ for CPE. Under these conditions the currents were diffusion controlled. The relationship between peak potential and the logarithm of the scan rate (Figure $8(\mathrm{~b}), y=0.14 x+0.39$, the correlation coefficient $r=0.9906$ for Pt electrode; $y=0.13 x+0.55$, the correlation coefficient $r=0.9950$ for CPE) can be used to roughly estimate the number of electrons involved in the catalytic oxidation.

\section{Structure and Reactivity}

The two linear portions [plotted for $(\mathrm{p} K-1)>\mathrm{pH}>$ $(\mathrm{p} K+1)]$ intersect at a $\mathrm{pH}$ value corresponding to $\mathrm{pK}$. The $E_{1 / 2}$ and $\mathrm{pH}$ values were input into the computer and using the simple regression method of the regression analysis the best two equations were found. These were solved to find the $\mathrm{p} K$ values. The $E_{1 / 2} v s$. $\mathrm{pH}$ plot of $\alpha$-asarone on $\mathrm{Pt}(\mathrm{p} K=4.60)$ and CPE ( $K K=4.88)$ electrodes were given in Figure 9. By using the substituent constant $\left(\delta_{\mathrm{H}}\right)$ value of trans-anethole as 0 , the other substituent constants $\left(\delta_{\mathrm{x}}\right)$ of fragrances calculated from $\mathrm{p} K_{\mathrm{H}}-\mathrm{p} K_{\mathrm{x}}$ are $-0.30,-0.40,-0.57,-2.0,-1.0$, for eugenol, $\alpha$-asarone, safrole, estragole, and isoeugenol, respectively. Most of the data may be correlated by a modified Hammett equation, $E_{1 / 2}=\rho \delta_{\mathrm{x}}, \rho(-1.15)$ is a voltammetric reaction constant. The Hammett $\delta$ - $\rho$ linear free-energy relationship is useful for evaluating substituent effects in a system. The rate of oxidation is greatly increased by the electron-donating substituent (-OH and-OMe). 


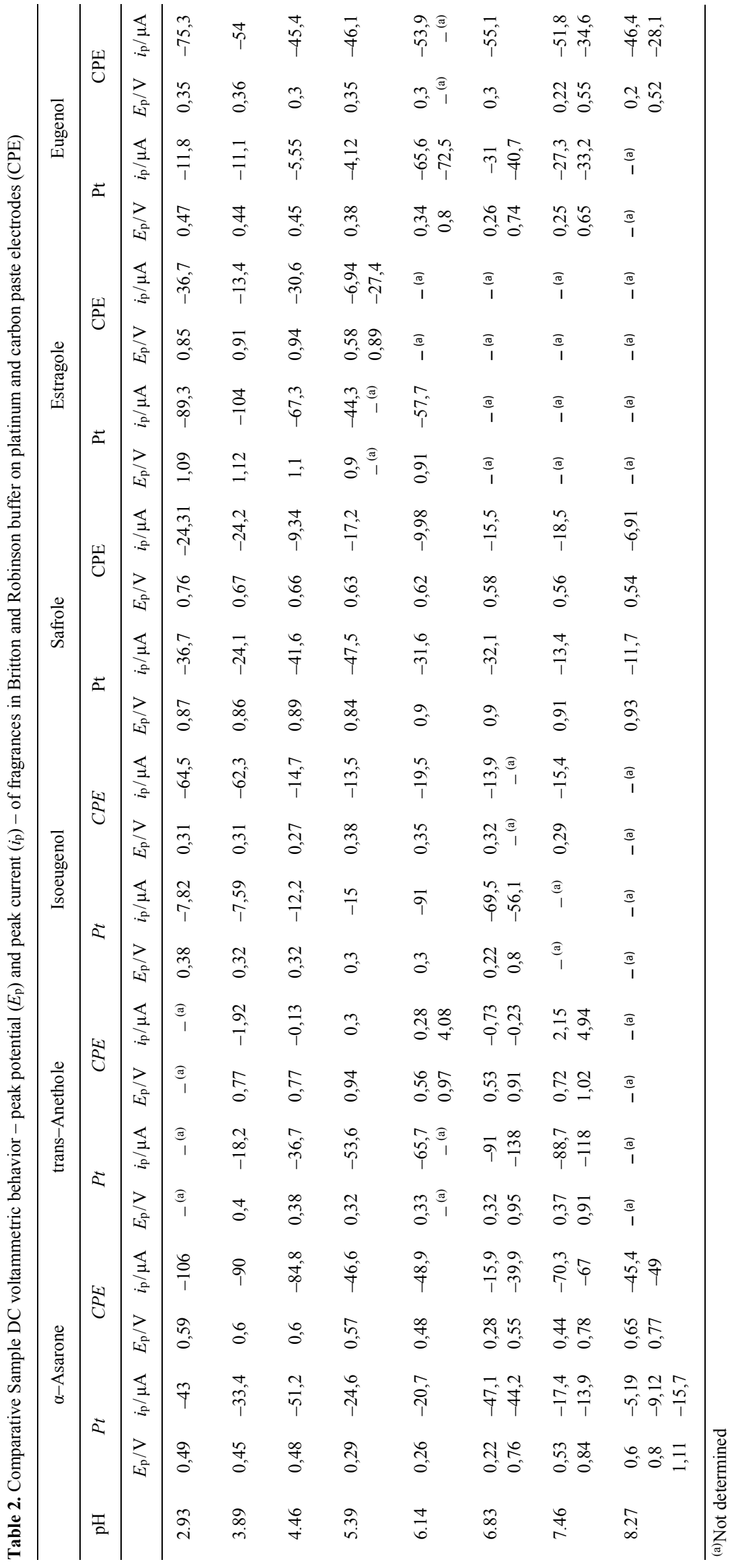




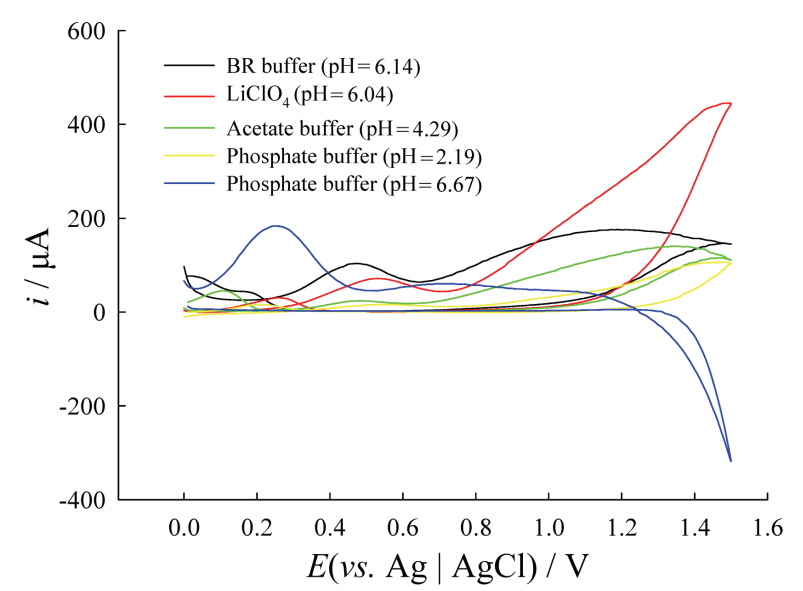

Figure 7. The effect of $\mathrm{pH}$ on the voltamograms for $9.09 \times$ $10^{-4} \mathrm{M}$ of trans-anethole on platinum electrode and scan rate $50 \mathrm{mV} / \mathrm{s}$. Britton-Robinson buffer solution $(\mathrm{pH}=6.14$, black line); $\mathrm{LiCLO}_{4}(\mathrm{pH}=6.04$, red line); acetate buffer $(\mathrm{pH}=4.29$, green line); phosphate $(\mathrm{pH}=2.09$, yellow line $)$; phosphate $(\mathrm{pH}$ $=6.67$, blue line).

The positive potential order is estragole $>$ safrole $>$ eugenol due to the $-\mathrm{OH}$ strongly activating group than $-\mathrm{OMe}$ in the para-position. However, the overall rate enhancement arises from a sum of the groups' inductive and resonance effects. Therefore, 4-propenylbenzenes (isoeugenol, $\alpha$-asarone, and trans-anethole) have both inductive and resonance effects. The same substituents in the 4-allyl (eugenol) and 4-propenylbenzenes (isoeugenol), when there is isoeugenol through-resonance between a reaction site that becomes electron-rich. Thus, the potential of isoeugenol shifts is less positive
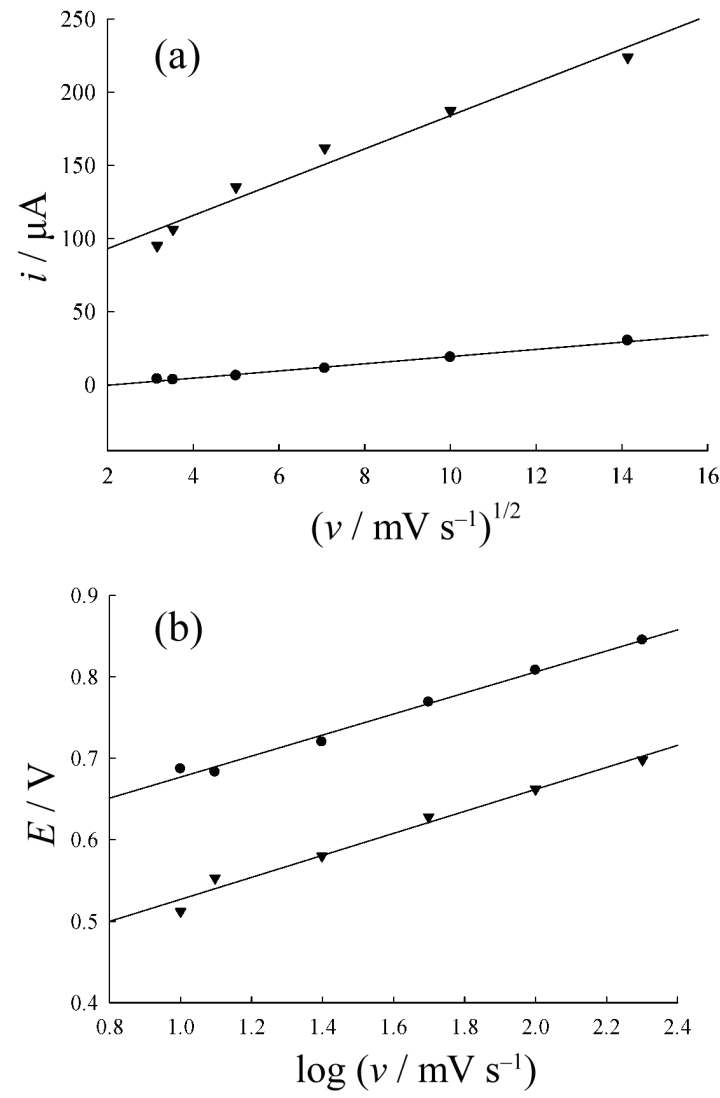

Figure 8. Magnitude of the peak current for isoeugenol oxidation as a function of square root of scan rate on $\mathrm{Pt}(\boldsymbol{\nabla})$ and CPE (•) electrodes (a); and peak potentials of isoeugenol oxidation as a function of logarithm of scan rates on $\mathrm{Pt}(\boldsymbol{\nabla})$ and CPE (•) electrodes (b).

Table 3. Comparative linear sweep voltammetric behavior of fragrances in Britton-Robinson buffer on platinum (Pt) and carbon paste electrodes (CPE) where $E_{\mathrm{p}}$ is peak potential, and $E_{\mathrm{p} / 2}$ is half-peak potential

\begin{tabular}{|c|c|c|c|c|}
\hline \multirow{3}{*}{$\mathrm{pH}$} & \multicolumn{2}{|c|}{$\alpha$-Asarone } & \multicolumn{2}{|c|}{ Eugenol } \\
\hline & $\mathrm{Pt}$ & $\mathrm{CPE}$ & $\mathrm{Pt}$ & $\mathrm{CPE}$ \\
\hline & $\left(E_{\mathrm{p}}-E_{\mathrm{p} / 2}\right) / \mathrm{mV}$ & $\left(E_{\mathrm{p}}-E_{\mathrm{p} / 2}\right) / \mathrm{mV}$ & $\left(E_{\mathrm{p}}-E_{\mathrm{p} / 2}\right) / \mathrm{mV}$ & $\left(E_{\mathrm{p}}-E_{\mathrm{p} / 2}\right) / \mathrm{mV}$ \\
\hline 2.93 & 180 & 180 & 100 & 90 \\
\hline 3.89 & 190 & 190 & 100 & 90 \\
\hline 4.46 & 170 & 190 & 100 & 80 \\
\hline 5.39 & 140 & 190 & 100 & 80 \\
\hline 6.14 & 90 & 160 & 170 & 100 \\
\hline 6.83 & $\begin{array}{l}120 \\
170\end{array}$ & $\begin{array}{l}140 \\
100\end{array}$ & $\begin{array}{l}130 \\
170\end{array}$ & $\begin{array}{l}80 \\
-{ }^{(a)}\end{array}$ \\
\hline 7.46 & $\begin{array}{l}50 \\
40\end{array}$ & $\begin{array}{l}100 \\
100\end{array}$ & $\begin{array}{l}140 \\
160\end{array}$ & $\begin{array}{l}80 \\
-{ }^{(a)}\end{array}$ \\
\hline 8.27 & $\begin{array}{l}70 \\
60\end{array}$ & $\begin{array}{c}50 \\
160\end{array}$ & $\begin{array}{l}-^{(a)} \\
-{ }^{(a)}\end{array}$ & $\begin{array}{l}80 \\
-{ }^{(a)}\end{array}$ \\
\hline 8.81 & $\begin{array}{l}70 \\
60\end{array}$ & $\begin{array}{c}70 \\
120\end{array}$ & $\begin{array}{l}-^{\text {(a) }} \\
\text { (a) }^{\text {(a) }}\end{array}$ & $\begin{array}{l}-^{\text {(a) }} \\
-^{\text {(a) }}\end{array}$ \\
\hline
\end{tabular}

\footnotetext{
${ }^{(a)}$ Not determined
} 


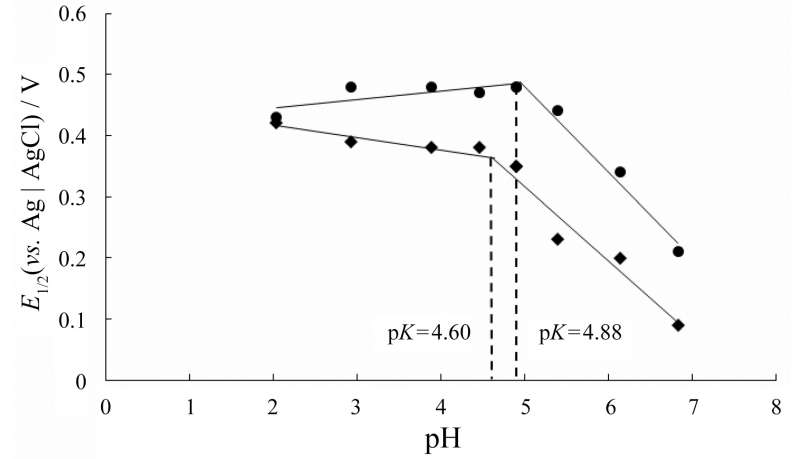

Figure 9. The relations of $E_{1 / 2}$ and $\mathrm{pH}$ of $\alpha$-Asarone on $\mathrm{Pt}(\bullet)$ and $\mathrm{CPE}(\bullet)$ electrodes.

than that of eugenol. The same as substituents of transanethole and eatragole in the benzene, likewise the potential of trans-anethole shifts less positively than that estragole.

\section{CONCLUSION}

The fragrances of the ally and propenyl derivatives of phenol and phenol ethers have similar of the irreversible oxidation potentials, and their potential is closely dependent on the structural factors. Thus, compared with various electron-donating groups and conjugation results on platinum and carbon paste electrodes.

Acknowledgements. This work was financially supported by a grant from the National Science Council of the Republic of China (NSC 96-2113-M-041-003-MY3).

\section{REFERENCES}

1. D. Belsito, D. Bickers, M. Bruze, P. Calow, H. Greim, J. M. Hanifin, A. E. Rogers, J. H. Saurat, I. G. Sipesi, and H. Tagamij, Food Chem. Toxicol. 48 (2010) S1-S46.

2. Jan C. R. Demyttenaere, Ch. 22, in: K. Hüsnü C. Başer, and G. Buchbauer (Eds.), Handbook of Essential Oils, Boca Raton, London, New York, CRC Press/Taylor \& Francis, 2010, pp. 917-948.

3. I. A. Southwell, M. F. Russell, and N. W. Davies Flavour Fragr. J. 26 (2011) 336-340.
4. T. Karunasekara and C. F. Poole J. Chromatogr. A. 1235 (2012) 159-165.

5. S. Furlanetto, S. Orlandini, I. Giannini, B. Pasquini, and S. Pinzauti Talanta 83 (2010) 72-77.

6. T. Shibamoto and S. Mihara Journal of Toxicology, Cut.\& Ocular Toxico. 2 (1984) 275-276.

7. H. H. Schunk, T. Shibamoto, H. K.Tan, and C. I. Wei Dev. in Food Sci. 18 (1988) 1045-1068.

8. S. Mihara and T. Shibamoto J. Agric. Food Chem. 30 (1982) 1215-1218.

9. Y. G. Davcheva, S. K. Ivanov, Z. D. Kalitchin, and S. A. Ivanov Oxid. Commun. 17 (1994) 17-23.

10. H. C. Chiang and S. Y. Li J. Chin. Chem. Soc. 25 (1978) 141147.

11. G. Leary Aust. J. Chem. 30 (1977) 1133-1136.

12. Y. H. Kuo, L. H. Chen, and L. M.Wang Jap. Chem. Pharm. Bull. 39 (1991) 2196-2000.

13. K. Eskins Photochem. Photobio. 29 (1979) 609-610.

14. E. M. Elgendy and S. A. Khayyat Russ. J. Org. Chem. 44 (2008) 823-829.

15. L. H. Wang, C. C. Wang, and S. K. Chuang Asian J. Chem. 22 (2010) 3835-3842.

16. L. H. Wang and J. C. Chen Curr. Pharm. Anal. 7 (2011) 88-94.

17. A. Cihaner, H. N. Testereci, and A. M. Onal Eur. Polym. J. 37 (2001) 1747-1752.

18. A. Ciszewski and G. Milczarek Electroanalysis 13 (2001) 860 867.

19. C. Demaille and A. J. Bard Acta Chem. Scand. 53 (1999) 842848.

20. X. J. Tang, J. J.Liang, X. Yan, and P. H. Li Huaxue Gongchengshi 22 (2008) 59-62.

21. I. M. Osadchenko and A. P. Tomilov Russ. J. Appl. Chem. 79 (2006) 2035-2036.

22. Q. L. Zhong, X. H. Zhang, X. Q. Su, L. Zhang, Y. L. Liu, B. Ren, and Z. Q. Tian Wuli Huaxue Xuebao 20 (2004) 94-97.

23. I. Barba, R. Chinchilla, and C. Gomez J. Org. Chem. 55 (1990) 3270-3272.

24. D. T. Sawyer and J. L. Roberts, Experimental electrochemistry for chemists, John Wiley \& Son, Inc., 1979, p. 184.

25. C. Mousty and G. Mousset New J. Chem. 16 (1992) 1063-1070.

26. M. Blazquez, J. M.; Rodriguez-Mellado, and J. J. Ruiz Electrochim. Acta 30 (1985) 1527-1532.

27. M. Iguchi, A. Nishiyama, Y. Terada, and S. Yamamura Anal. Lett. 12 (1979) 1079-87.

28. P. Zuman and C. L.; Perrin, Organic polography, John Wiely \& Son., 1969, p. 292.

29. C. D. Johnson, The Hammett equation, Cambridge University Press, 1973, p.11. 